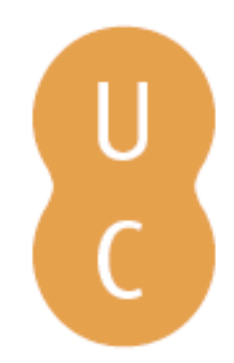

\title{
nommalina
}

\section{Action planning fosters adoption of regular physical activity behavior among low- control individuals with high intention}

Autor(es): $\quad$ Chamberland, Pier-Eric; Miquelon, Paule

Publicado por: Imprensa da Universidade de Coimbra

URL

persistente: URI:http://hdl.handle.net/10316.2/38620

DOI: $\quad$ DOI:http://dx.doi.org/10.14195/978-989-26-0775-7_16

Accessed : $\quad$ 26-Apr-2023 12:20:56

A navegação consulta e descarregamento dos títulos inseridos nas Bibliotecas Digitais UC Digitalis, UC Pombalina e UC Impactum, pressupõem a aceitação plena e sem reservas dos Termos e Condições de Uso destas Bibliotecas Digitais, disponíveis em https://digitalis.uc.pt/pt-pt/termos.

Conforme exposto nos referidos Termos e Condições de Uso, o descarregamento de títulos de acesso restrito requer uma licença válida de autorização devendo o utilizador aceder ao(s) documento(s) a partir de um endereço de IP da instituição detentora da supramencionada licença.

Ao utilizador é apenas permitido o descarregamento para uso pessoal, pelo que o emprego do(s) título(s) descarregado(s) para outro fim, designadamente comercial, carece de autorização do respetivo autor ou editor da obra.

Na medida em que todas as obras da UC Digitalis se encontram protegidas pelo Código do Direito de Autor e Direitos Conexos e demais legislação aplicável, toda a cópia, parcial ou total, deste documento, nos casos em que é legalmente admitida, deverá conter ou fazer-se acompanhar por este aviso.

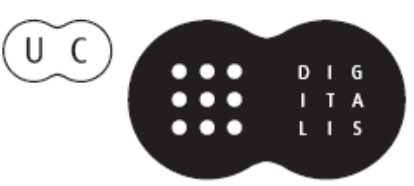




\section{INTERNATIONAL \\ STUDIES IN TIME \\ PERSPECTIVE}

MARIA PAULA PAIXÃO

JOSÉ TOMÁS DA SILVA

(COORD.)

VICTOR ORTUÑO

PEDRO CORDEIRO

(EDITORS)

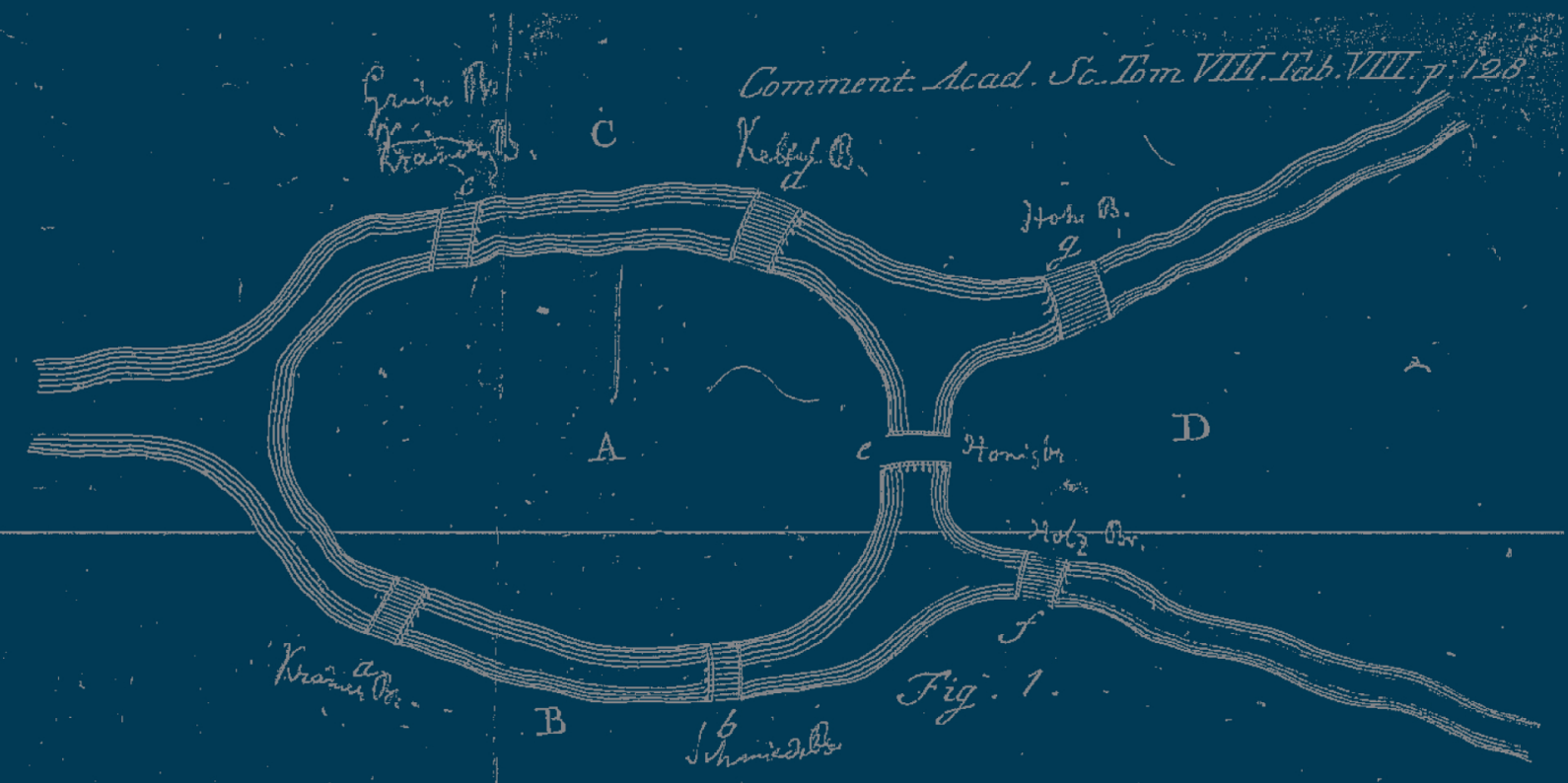

IMPRENSA DA

UNIVERSIDADE

DE COIMBRA

COIMBRA

UNIVERSITY

PRESS 


\title{
Chapter 16 \\ ACTION PLANNING FOSTERS ADOPTION OF REGULAR PHYSICAL ACTIVITY BEHAVIOR AMONG LOW-CONTROL INDIVIDUALS WITH HIGH INTENTION
}

\author{
Pier-Eric Chamberland \\ Paule Miquelon \\ University of Quebec, Canada \\ pier.e.chamberland@gmail.com
}

\begin{abstract}
Aвstract: This study aims to document how action planning (AcP) and coping planning (CP) (Gollwitzer, 1999) combines with the intention and perceived behavioral control (PBC) variables (Ajzen, 1991) to predict physical activity (PA) behavior. It was hypothesized that: 1) intention and the use of planning would each have a main effect on PA behavior, 2) AcP, with or without CP, would be useful to individuals with low PBC if their intention was high. In a quasi-experimental prospective design, 122 individuals were asked to engage regularly in PA for the 5 following weeks with the help of AcP alone, AcP and CP, or no planning at all. TPB variables and past month PA behavior were measured at T1 and frequency of PA was measured at T2. Results of an ANCOVA 2 (low vs high intention) X 3 (no planning, AcP, AcP + CP) X 3 (low, average or high $\mathrm{PBC}$ ), which controlled for the influence of past behavior, revealed a main effect of intention and a significant interaction between intention, planning and PBC. Simple effects analysis demonstrated that AcP alone improved PA frequency among low PBC individuals with high intention. Limits of the design as well as conceptual implications are discussed.
\end{abstract}

Keywords: physical activity, action and coping planning, intention, perceived behavioral control.

\section{BACKGROUND}

Optimal functioning and self-regulation of goals, including health goals like regular physical activity (PA), are ideally attained through future-oriented and eudaemonic mindsets (Miquelon \& Vallerand, 2008; Oettingen, 2000; Zimbardo \& Boyd, 1999). Goal setting and planning (or implementation intentions, IIs, Gollwitzer, 1999) are integral parts of these processes (Gollwitzer \& Oettingen, 2011) and planning can even compensate for the goal striving deficits associated with a limited time perspective (Gellert et al., 2012). Concurrently, research by Bayer, Gollwitzen \& Achtzigen (2010) suggested that IIs also contribute to acquire a concrete and present-centered mindset called hypoegoic self-regulation, in which conscious thoughts conflicting with execution of action (i.e. self-defeating emotions or temptations) are silenced, thus fostering flow experience and reducing self-regulatory expenditure (Leary \& Guadagno, 2011). Effective goal intentions and planning go hand in hand (Mele, 2009), as intention alone appears to be insufficient to foster behavior change (intention-behavior gap, Sheeran, 2002). Indeed, IIs were shown to be significant intention-PA mediators, induced IIs having small to medium effect sizes 
(Bélanger-Gravel et al., 2011; Carraro \& Gaudreau, 2012) and spontaneous IIs having medium to large effect sizes (Carro \& Gaudreau, 2012). Both subtypes, action planning (AcP, specifying where, when $\&$ how to exercise) and coping planning (CP, identifying obstacles to exercise and the means to overcome them, Sniehotta et al., 2005), have been used with success, separately or in combination, within interventions to increase PA (Carraro \& Gaudreau, 2012).

\section{Purpose and hypotheses}

To our knowledge, the benefits of AcP combined with CP have never been compared to those obtained with AcP alone. Also, few studies focused on differential effects of $\mathrm{AcP}$ and $\mathrm{CP}$ on different profiles of exercisers. For example, since perceived behavioral control (PBC) has its own main effect on PA behavior (Ajzen, 1991), some people have the intention to exercise regularly but lack the confidence in succeeding to do so over a long period of time. Concurrently, past experience facilitates enactment of behavior (Ajzen, 2002) and is likely to impact positively on PBC. For these reasons, we aimed to investigate the possibly increased benefits of combining AcP and CP, and the potential of AcP, with or without CP, to help people with limited PA experience increase their practice of PA. In brief, we expected past behavior, intention and planning to have a main effect on PA behavior, as well as a three-way interaction between $\mathrm{PBC}$, intention and planning. We also hypothesized that AcP, with or without $\mathrm{CP}$, would be useful to individuals with low PBC if their intention was high.

\section{Method}

In order to verify these hypotheses, we used a prospective quasi-experimental design with IIs being experimentally manipulated. Two waves of data were collected from a sample of 140 French-Canadian adults (109 women \& 31 men, mean age: 31.5 years, S.-E. = 1.0 years) recruited through newspaper ads and on-the-spot solicitation at the Center for sports and PA of University of Québec at Trois-Rivières. Participants were required to present no pre-existing condition that might hinder the practice of PA and not already be regular exercisers (practicing PA less than 3 times a week). They were also invited to engage in moderate PA for at least 30 minutes, three days per week, over the following five weeks. The survey protocol consisted of two web-based questionnaires (pre and post-test), filled in an interval of 4 to 5 weeks.

The first questionnaire (T1) contained scales measuring past and current moderate PA frequency (adapted from Godin \& Shephard, 1997), intention and PBC toward PA (3 and 6 items, Boudreau \& Godin, 2009). At the end of this questionnaire, each participant was randomly assigned to one of the following conditions: a) a control group with no induced planning, b) a group forming AcP only and c) a group forming both AcP and CP. Adopting Sniehotta and colleagues (2005)' procedure, participants forming AcP were instructed to write down where, when and how they intended to practice PA over the following five weeks, while those forming both AcP and CP were also asked to list what obstacles where most likely to hinder their PA goals over that time and what means they chose to overcome 
them efficiently. Participants in the control group were not asked any questions about planning. The second questionnaire (T2) measured the weekly frequency of PA over the last five weeks on a 7-point Likert Scale (adapted from Godin \& Shephard, 1997). An analysis of covariance (ANCOVA) 2 (low vs. high intention) X 2 (low vs. high PBC) X 3 (conditions $\mathrm{a}, \mathrm{b}$, and $\mathrm{c}$ ), controlling for the effect of past PA frequency, was used to analyze the data, as well as planned contrasts and pairwise comparisons with Bonferroni correction to identify significant differences. The median was used as a cut-off point to create upper and lower intention and $\mathrm{PBC}$ categories.

\section{RESUlts}

Table 1 - Effects of past PA, intention, PBC and planning on PA frequency at T2

\begin{tabular}{|l|c|c|c|c|c|c|}
\hline Source & df & Type 1 SS & MS & F & $p$ & $\eta^{2}$ \\
\hline Past PA frequency & 1 & 8,307 & 8,307 & 6,154 &, 014 &, 046 \\
\hline Intention & 1 & 9,562 & 9,562 & 7,084 &, 009 &, 053 \\
\hline PBC & 1 & 3,745 & 3,745 & 2,774 &, 098 &, 021 \\
\hline Condition & 2 & 5,606 & 2,803 & 2,077 &, 130 &, 032 \\
\hline Condition*intention & 2 &, 784 &, 392 &, 291 &, 748 &, 005 \\
\hline Condition*PBC & 2 &, 163 &, 081 &, 060 &, 942 &, 001 \\
\hline Cond. ${ }^{*}$ intention*PBC & 3 & 13,867 & 4,622 & 3,424 &, 019 &, 075 \\
\hline Error & 127 & 171,429 & 1,350 & & & \\
\hline Total & 140 & 823,739 & & & & \\
\hline Corrected Total & 139 & 213,463 & & & & \\
\hline
\end{tabular}

Planned contrasts revealed a significant difference between control and experimental groups, $\mathrm{F}(1,127)=8.72, p=.004$, but not between experimental groups $(p=.31)$. Results of the ANCOVA are presented in Table 1. Past PA frequency and intention had significant effects on PA frequency at T2 ( $p=.014$ and $p=.009)$. Although no effects were found for $\mathrm{PBC}$ and the experimental conditions $(p>.05)$, an interaction between intention, $\mathrm{PBC}$ and the experimental conditions was found $(p=.019)$. Pairwise comparisons indicated that the significant contrast was between AcP and the control group for participants included in the high intention and low $\mathrm{PBC}$ categories. More precisely, AcP users showed higher PA frequency than the control group $(p=.021)$. The difference between the group using both $\mathrm{AcP}$ and $\mathrm{CP}$ and the control group was not significant. Also, among low-PBC AcP users, participants in the high intention category showed higher PA frequency than participants in the low intention category $(p=.022)$. Interestingly, participants with low intention and high PCB using AcP showed higher PA frequency than those who did not, but that difference was only marginally significant $(p=.056)$. 


\section{DiscusSION AND CONCLUSION}

Our first hypothesis was partially supported, since only past frequency of PA and intention had main effects on PA frequency at T2. No main effects were found for PBC and the experimental conditions but the two variables interacted with intention altogether. The experimental conditions' effect size suggests that increasing sample size would help reach significance in future research. By contrast, our second hypothesis was supported: AcP combined with high intention improved PA frequency in individuals with low PBC. Small sample size might be responsible for the lack of significant differences between the group using AcP only and the group using AcP combined with CP. Nevertheless, the group using both AcP and CP had the highest increase in PA frequency between T1 and T2 in the sample, although it was not significant compared to other groups. A complementary effect of CP might have emerged over a longer time period, once the behavior was installed through AcP.

Overall, these findings are consistent with the intention-behavior mediation found by Conner et al. (2010), which revealed that planning is more efficient when intentions to exercise are strong. They also contrast with findings of Luszczynska and Haynes (2009), which reported that self-efficacy must be sufficiently high for the plans to work. Self-efficacy and $\mathrm{PBC}$ being conceptually distinct, this could raise the question of whether planning boosted self-efficacy in people with low PBC. The marginally significant difference between AcP users and control group for low-intention-high PBC profiles suggests that the effect of plans may not be limited to the intentional stage (Carraro \& Gaudreau, 2012). Further research is necessary to document the effect of provided planning in pre-intentional stages.

In sum, AcP seems to have a beneficial effect on PA behavior for individuals who have low confidence in their ability, but this is conditional to intention: volition is still necessary. Results suggest that first-timers can concentrate on getting started with AcP before considering CP, which should be more useful in maintenance (Scholz et al., 2008). In addition to the formulation stage-appropriate specific plans, they also highlight the importance of sustaining volition over time, hence self-regulatory effort, as proposed by Hall, Fong \& Cheng (2011), and Hagger et al. (2010).

\section{REFERENCES}

Ajzen, I. (1991). The theory of planned behavior. Organizational Behavior and Human Decision Processes, 50(2), 179-211.

Ajzen, I. (2002). Residual effects of past on later behavior: Habituation and reasoned action perspectives. Personality and Social Psychology Review, 6(2), 107-122.

Bayer, U. C., Gollwitzer, P. M., \& Achtziger, A. (2010). Staying on track: Planned goal striving is protected from disruptive internal states. Journal of Experimental Social Psychology, 46(3), 505$-514$.

Bélanger-Gravel, A., Godin, G., \& Amireault, S. (2013). A meta-analytic review of the effect of implementation intentions on physical activity. Health Psychology Review. 7(1). 23-54.

Boudreau, F., \& Godin, G. (2009). Understanding physical activity intentions among French Canadians with type 2 diabetes: An extension of Ajzen's theory of planned behaviour. International Journal of Behavioral Nutrition and Physical Activity, 6(1), 1-11. 
Carraro, N., \& Gaudreau, P. (revise and resubmit). Spontaneous and experimentally induced action planning and coping planning for physical activity: A meta-analytic review. Psychology of Sport and Exercise.

Conner, M., Sandberg, T., \& Norman, P. (2010). Using action planning to promote exercise behavior. Annals of Behavioral Medicine, 40(1), 65-76.

Gellert, P., Ziegelmann, J. P., Lippke, S., \& Schwarzer, R. (2012). Future time perspective and health behaviors: Temporal framing of self-regulatory processes in physical exercise and dietary behaviors. Annals of Behavioral Medicine, 43(2), 208-18.

Godin, G., \& Sheppard, J. A. (1997). Godin leisure-time exercise questionnaire. Medicine and Science in Sports and Exercise, 29, June Supplement: S36-S38.

Godin, G., Bélanger-Gravel, A., Amireault, S., Gallani, M. C. B. J., Vohl, M. C., \& Pérusse, L. (2010). Effects of implementation intentions to change behavior: moderation by intention stability. Psychological Reports, 106(1), 147-159.

Gollwitzer, P. M. (1999). Implementation intentions: Strong effects of simple plans. American Psychologist, 54, 493-503.

Gollwitzer, P. M., \& Oettingen, G. (2011). Self-regulation and behavior change: Disentangling behavioral initiation and behavioral maintenance. In K. D. Vohs \& R. F. Baumeister (Eds.), Handbook of self-regulation: Research, theory, and applications (pp. 162-185). New York: Guilford Press.

Hagger, M. S., Wood, C. W., Stiff, C., \& Chatzisarantis, N. L. D. (2010). Self-regulation and self-control in exercise: The strength-energy model. International Review of Sport and Exercise Psychology, 3(1), 62-86.

Hall, P. A., Fong, G. T., \& Cheng, A. Y. (2012). Time perspective and weight management behaviors in newly diagnosed type 2 diabetes: A mediational analysis. Journal of Behavioral Medicine, 35(6). 569-580.

LeAry, M. R., \& Guadagno, J. (2011). The role of hypo-egoic self-processes in optimal functioning and subjective well-being. In K. M. Sheldon, T. B. Kashdan, \& M. F. Steger (Eds.), Designing positive psychology: Taking stock and moving forward (pp. 135-46). New York: Oxford University Press.

Luszczynska, A., \& Haynes, C. (2009). Changing nutrition, physical activity and body weight among student nurses and midwives. Journal of Health Psychology, 14(8), 1075-1084.

Mele, A. R. (2009). Effective intentions : The power of conscious will. Oxford; New York: Oxford University Press.

Miquelon, P., \& Vallerand, R. J. (2008). Goal motives, well-being, and physical health: An integrative model. Canadian Psychology/Psychologie Canadienne, 49(3), 241-249.

Oettingen, G. (2000). Expectancy effects on behavior depend on self- regulatory thought. Social Cognition, 18, 101-129.

Reuter, T., Ziegelmann, J. P., Wiedemann, A. U., Lippke, S., Schüz, B., \& Aiken, L. S. (2010). Planning bridges the intention--behaviour gap: Age makes a difference and strategy use explains why. Psychology and Health, 25(7), 873-887.

Scholz, U., Schüz, B., Ziegelmann, J. P., Lippke, S., \& Schwarzer, R. (2008). Beyond behavioural intentions: Planning mediates between intentions and physical activity. British Journal of Health Psychology, 13(Pt 3), 479-94.

Sheeran, P. (2002). Intention-behaviour relations: A conceptual and empirical review. European Review of Social Psychology, 13, 1-36. 
Sniehotta, F. F., Schwarzer, R., Scholz, U., \& Schuz, B. (2005). Action planning and coping planning for long-term lifestyle change: Theory and assessment. European Journal of Social Psychology, 35, 565-576.

Zimbardo, P. G., \& Boyd, J. N. (1999). Putting time in perspective: A valid, reliable individualdifferences metric. Journal of Personality and Social Psychology, 77(6), 1271-1288. 